\title{
FAKTOR PENDAPATAN KELUARGA TERHADAP PERDARAHAN POST PARTUM
}

\author{
Beatrix Selena $^{1 *}$, Salsabila $^{1}$, Kartin $^{1}$, A.Fahira Nur ${ }^{2}$ \\ ${ }^{1}$ Mahasiswa Kebidanan STIKES Widya Nusantara Palu \\ ${ }^{2}$ Bagian Kebidanan STIKES Widya Nusantara Palu
}

\section{*E-mail:beatrixselena09@gmail.com}

\begin{abstract}
Pemberian asuhan kebidanan kepada ibu dalam masa nifas sangat penting dilakukan yang bertujuan untuk menjaga kesehatan ibu dan bayi, melaksanakan deteksi dini adanya komplikasi dan infeksi, memberikan pendidikan pada ibu serta memberikan pelayanan kesehatan pada ibu dan bayi. Selama masa nifas ibu akan mengalami perubahan. Pelayanan atau asuhan merupakan cara penting untuk memonitor dan mendukung kesehatan ibu nifas normal dan mengetahui secara dini bila ada penyimpangan yang ditemukan dengan tujuan agar ibu dapat melalui masa nifasnya dengan selamat.

Berikut ini penulis akan membahas tentang hubungan pendapatan keluarga terhadap perdarahan post partum.

1. Tinjauan tentang perdarahan post partum

Perdarahan pasca persalinan didefinisikan sebagai kehilangan $500 \mathrm{ml}$ atau lebih darah setelah persalinan pervaginam atau $1000 \mathrm{ml}$ atau lebih setelah seksio sesaria ${ }^{1}$ Menurut waktu terjadinya dibagi atas dua bagian .Perdarahan postpartum primer (early postpartum hemorrhage) ialah perdarahan $>500 \mathrm{cc}$ yang terjadi dalam 24 jam pertama setelah bayi lahir. Penyebab utama perdarahann postpartum primer adalah atonia uteri, retensio plasenta, sisa plasenta dan robekan jalan lahir.Perdarahan postpartum sekunder (late postpartum hemorrhage) ialah perdarahan $>500 \mathrm{cc}$ setelah 24 jam pasca persalinan. Penyebab utama perdarahan postpartum sekunder adalah robekan jalan lahir dan sisa plasenta. ${ }^{1}$
\end{abstract}


2. Tinjauan terhadap pendapatan keluarga

Tingkat pendapatan berpengaruh terhadap status kesehatan individu. Dengan ditunjukkan bahwa semakin meningkat pendapatan kepala rumah tangga, maka peluang angota rumah tangga dengan status kesehatan buruk akan menurun. Dilihat dari peluang mengalami sakit, dengan pendapatan dibawah maupun diatas semua berpeluang mengalami perdarahan. Upaya peningkatan kesehatan baik berkaitan dengan kemampuan ekonomi dengan tingkat pendapatan dan kondisi lingkungan sosial anggota rumah tangga. Lingkungan sosial anggota rumah tangga. Bagai-mana ilmu-ilmu ekonomi berperan dalam lingkup tuntutan kesehatan setiap individu. ${ }^{1,2}$

3. Tinjauan tentang hubungan pendapatan keluarga terhadap perdarahan post partum.

Pendapatan memiliki pengaruh secara tidak langsung terhadap kejadian perdarahan postpartum. Keluarga dengan pendapatan tinggi akan mampu memenuhi kebutuhan gizi. Sebaliknya keluarga dengan pendapatan rendah akan kesulitan dalam memenuhi kebutuhan gizi ${ }^{1}$

Wanita dengan pendapatan rumah tangga lebih rendah memiliki risiko lebih tinggi terkena perdarahan perdarahan postpartum dibandingkan dengan wanita yang berpendapatan lebih tinggi ${ }^{1}$ 


\section{Daftar Pustaka}

1. Nur,Fahira A 2017.Faktor Risiko Kejadian Perdarahan Postpartum Di Rumah Sakit Umum (Rsu) Anutapura Palu. Palu :Healthy Tadulako Journal.http://jurnal.untad.ac.id/jurnal/index.php/HealthyTadulako/article/view/12622/9765. Di akses tanggal 11 oktober 2019.

2. Gurning, F. 2004. Gambaran Kasus Perdarahan Post Partum di RSU Dr. Pirngadi Medan tahun 2000-2003. Skripsi 